\title{
sciendo
}

\section{IMPLEMENTATION OF CORPORATE SOCIAL RESPONSIBILITY IN CENTRAL EUROPE}

\author{
Art Kovačič, \\ Faculty of Commercial and Business Studies, Lava 7, 3000 Celje, SLOVENIJA artkovacic@gmail.com
}

\begin{abstract}
Corporate Social Responsibility can be understand as a way for managing business activities which integrates economic, social and environmental aspects in harmony with principles of sustainable development that have a positive impact not only on our economic performance but also on our surroundings (employees, partners, customers, the city and region) with a consistent reduction of impacts on the environment via enduring development of human resources, the community and society. It is our continuous obligation to do business ethically, transparently and in accord with CSR principles and to contribute to the economic environment along with improvement in the quality of life of our employees, their families, the local community and, equally also, in society in the broader meaning of this word. Management in enterprises implement the Corporate Social Responsibility approach. Business sustainability is high in CEE enterprises.
\end{abstract}

KEYWORDS: economic development, benchmarking, development strategy, environmental economics JEL classification: 01, 024, 038, Q5

UDC: 339,9

\section{INTRODUCTION}

The sustainable development approach has to be implemented on business level. Management in enterprises needs to be responsible to social and environmental goals. In the article will test three hypothesis. First hypothesis is that business progress and environmental protection goes together hand in hand. Second hypothesis is Corporate Social Responsibility is a new approach in Central Europe.. Third hypothesis: business sustainability is very accepted in CEE enterprises. Corporate social responsibility (CSR) and sustainable development are all new concepts that were mostly unknown through Central Europe less than 20 years ago. Today we can see a growing number of companies in our region that consistently follow in the footsteps of the most advanced global enterprises, implementing strategic initiatives and thus increasing their contribution to sustainable social and economic growth. CSR is regarded as a universal concept based on the triple bottom line principle. But despite this widely acknowledged concept, its interpretation and popularity change over time and differ between regions. This applies not only to world regions such as the U.S. and Europe, but also on smaller scales, e.g. between Western Europe and Central and Eastern Europe (CEE). Europe is the continent that first dealt with the CSR movement. Europe boasts traditionally more consistent CSR values, norms and perceptions compared to other areas of the world. European corporations tend to hold stronger and broader approaches to stakeholder relations, and that network is being established to help companies share and diffuse relevant information about CSR. Through CSR, corporations importantly contribute to the EU's treaty objectives of sustainable development and highly competitive social market economy. While CSR has a particularly strong resonance in parts of Western Europe, it took root slowly in Central and Eastern Europe. Most companies consider their responsibility to operate in compliance with the legal and regulatory environment of the given country. "However, in recent years CSR a became a "hot" topic in Central and Eastern Europe. CEE countries are increasingly integrating themselves into the global political and economic system, and there is an emerging need to integrate corporate responsibility in the mainstream management education and executive education. Reputation remains the main focus of CSR in both Western and Eastern Europe. The main drivers for companies to adopt CSR in the CEE region is to protect brands and keep a company's 'licence to operate' — society's approval for their activities. The same is still true for many Western companies, but leaders moved on to addressing how sustainability affects the core business through innovation and strategy. CSR (or sustainability) reporting is taking a similar route. While people in the CEE region are slowly learning how to apply it, in the West most of the companies have already managed to leverage reporting into significant benefits. Committing to CSR reporting led companies to develop their stakeholder relationships and also to improve management communication systems. One of the notable benefits was the setup of public commitments, which assisted companies in moving forward. Now, the new systems have worked into the company culture and yearly reports do not require extra effort. In the CEE region, most of the big players are subsidiaries of multinational corporations normally headquartered elsewhere. Such subsidiaries are applying centrally managed CSR, customized to local laws and regulations. Only some would take the opportunity and make this process a competitive advantage. The other issue is starting a conversation about any type of government intervention; the legacy of communism is vividly remembered. It has to be clear governments should limit the use of sustainability promotion policy measures through market devices not through direct planning. Although, the stance on whether CSR should be regulated or remain voluntary is equally mixed. Corporate social responsibility (CSR) refers to business practices involving initiatives that benefit society. A business's CSR can encompass a wide variety of tactics, from giving away a portion of a company's 
proceeds to charity, to implementing "greener" business operations. The sustainable development on business level is more important through stakeholder approach. Stakeholder influence strategies should aim at both external pressures (regulations and market changes) and change in internal corporate factors (such as corporate culture) as a basis for affecting corporate environmental strategy and processes. A new strategy on Corporate Social Responsibility ('CSR'), which aims to take forward the contribution of business to sustainable development, was adopted by the European Commission. Corporate social responsibility (CSR) refers to companies taking responsibility for their impact on society. The European Commission believes that CSR is important for the sustainability, competitiveness, and innovation of EU enterprises and the EU economy. It brings benefits for risk management, cost savings, access to capital, customer relationships, and human resource management. The Commission (2016) has defined CSR as the responsibility of enterprises for their impact on society. CSR should be company led. Public authorities can play a supporting role through a smart mix of voluntary policy measures and, where necessary, complementary regulation. Companies can become socially responsible by: following the law; integrating social, environmental, ethical, consumer, and human rights concerns into their business strategy and operations. There are many reasons why is CSR so important. In the interest of enterprises CSR provides important benefits to companies in risk management, cost savings, access to capital, customer relationships, HR management, and their ability to innovate. In the interest of the $\mathbf{E U}$ economy CSR makes companies more sustainable and innovative, which contributes to a more sustainable economy. In the interests of society - CSR offers a set of values on which we can build a more cohesive society and base the transition to a sustainable economic system. The Commission (European Strategy on CSR, 2016) promotes CSR in the EU and encourages enterprises to adhere to international guidelines and principles. Through CSR, enterprises can significantly contribute to the European Union's treaty objectives of sustainable development and a highly competitive social market economy. CSR underpins the objectives of the Europe 2020 strategy for smart, sustainable and inclusive growth, including the $75 \%$ employment target. Responsible business conduct is especially important when private sector operators provide public services. Helping to mitigate the social effects of the current economic crisis, including job losses, is part of the social responsibility of enterprises. CSR offers a set of values on which to build a more cohesive society and on which to base the transition to a sustainable economic system. The sustainable development on business level is more important through stakeholder approach. Stakeholder influence strategies should aim at both external pressures (regulations and market changes) and change in internal corporate factors (such as corporate culture) as a basis for affecting corporate environmental strategy and processes. Alternatives for stakeholder influence include market pressure, sensitive property ownership, legislation/regulation, public policy influence, direct action (often counter-productive in coalitions), lawsuit, mediation/arbitration, dialog/voice and voting representation. Stakeholder theory holds that organizational performance ought to be judged by how effectively managers balance the interests of a multiplicity of external and internal constituents. In Sustainable development assessment we need an expectation of managers and business sector. The field of corporate social responsibility (CSR) shows to have become more important around the world. The role of business and the way it is perceived by society has gone through several changes throughout the history. Over time, until today, an increased awareness of the impact of business and its interaction with social and environmental issues have emerged. Companies are today obliged to some certain responsibilities in the society where they are active. The most basic responsibilities are laws and rules that they have to supply under. Organizations today are forced to show that their business stands for something more than just profits, and that their activities add some value, or at least do not negatively affect the community around them (Ledwidge, 2007). Van Marrewijk, (2003) defined CSR is regarded as the panacea which will solve the global poverty gap, social exclusion and environmental degradation. Boyd et al, (2007) defined corporate social responsibility as general sense reflects obligations to society and stakeholders within societies impacted by the firm. Beckman et al, (2009) pointed out that CSR known as the organization's status and activities with respect to its perceived community responsibility. CSR is developing in the ethics, marketing, and management fields. The ethics consists of three types of issues i.e., macro-, meso- and micro-level based. The macro- and meso- refer to stakeholder engagement and micro- is center of specific such as code of ethics.

\section{CORPORATE SOCIAL RESPONSIBILITY IN ENTERPRISES}

The process of CSR also includes environmental assessment, stakeholder management, and issues management. BeckerOlsen et al, (2006) mentioned that CSR a link between social initiatives and improved financial performance. According Besley and Ghatak, (2007) CSR is dependable with profitmaximization in competitive markets. In equilibrium firms sell ethical brands and neutral brands, and consumers selfselect according to their valuation of the public good. According to Margolis et al, (2007) the relationship between corporate social responsibility (CSR) and corporate financial performance across eight categories of CSR and found that different initiatives have significantly different impacts on financial performance. Pies et al, (2009) documented that the ordonomic approach can be used in business ethics to foster effective leadership skills and encourage CSR. The ordonomic perspective is a valuable framework for discussing the meaning and role of ethics in effective leadership and CSR in the age of globalization. The authors explained that the ordonomic approach provides a threetiered conceptual framework for analyzing society and social interaction. According to van Marrewijk, (2003) there the ultimate objective of CSR is to obtain Social Sustainability. This cannot be achieved without the different levels of CSR, in economy, social and environmental issues. In the shareholder approach it is clear that the central aim for a company is the pursuit of profit maximization and that the social responsible activities are not concerned with the corporate body but are a major task for the government and the public sector. In this process CSR is only interesting in the way that it contributes to achieve the objectives of the company, which in the long run is profitability for the owners."The implementation theories correspond to the basis to create a model that describes a CSR implementation process" According to Caroll, (1991) business and politics communities have been influenced by the globalisation process and the displacement of values from material to immaterial values that has taken place.Refer to a work by Garriga and Melé, (2004) the corporation is used strategic 
tool for wealth creation. There are three main groups of instrumental theories which depend on the economic objectives. Maximizing the shareholder value.According to the authors, any investment social demands that contribute to maximizing the shareholder without deception and fraud are include in this group. It has been noted that the shareholder value maximization as the supreme reference for corporate decision-making. The important element is Strategies for achieving competitive advantages. Garriga and Melé, (2004) noted that this group of theories are concentrated on long term social objectives by knowing how to allocate resource and create a competitive advantage. There are three approaches can be included within this strategies i.e., social investments in competitive context, natural resource-based view of the firm and its dynamic capabilities and strategies for the bottom of the economic pyramid. Cause-related marketing refers as the process of formulating and implementing marketing activities and the goal is to enhance company revenues, sales or customer relationship by building the brand through the acquisition of, and association with the ethical dimension or social responsibility dimension. It can be pointed out that political theories focus on interactions and connections between business and society and on the power of business and its inherent responsibility. There are two major theories can be distinguished through Corporate Constitutionalism and Corporate Citizenship.

Corporate citizenship refers as responsibilities and possible partnerships of business in society. It has been reported that some theories on corporate citizenship are based on a social contract theory. Corporate citizenship theories generally have a strong sense of business responsibility towards the local community, partnerships which are the specific ways of formalizing the willingness to improve the local community and for consideration for the environment. (Garriga and Melé, 2004). According to the authors, the integrative theories depend to social demands for its existence continuity and growth. Social demands means society interacts with business and gives it a certain legitimacy and prestige. In addition, the authors noted that the theories of this group are focused on the detection and scanning of, and response to, the social demands that achieve social legitimacy, greater social acceptance and prestige. The concept of social responsiveness broadens with the concept of issue management which refers as a process for making a corporate response to social issues. Issues management is a process of the corporation can identify, evaluate and respond to those social and political issues which may impact significantly upon it. Public policy consists of law, regulation and broad pattern of social direction reflected to public opinion, emerging issues, formal legal requirements and enforcement or implementation practices. Garriga and Melé, (2004) noted that "if business adhered to the standards of performance in law and the existing public policy process, then it would be judged acceptably responsive in terms of social expectations". Stakeholder management focuses on the public responsibility principle and combines groups with a stake in the firm into managerial decision making. Refer to Garriga and Melé, (2004) the corporate social performance theories includes social legitimacy with process for giving appropriate responses. The corporate social performance also include the principles of CSR, expressed on institutional, organizational and individual levels, processes of corporate social responsiveness, such as environmental assessment, stakeholder management and issues management, and outcomes of corporate behavior including social impacts, social programs and social policies. Garriga and Melé, (2004) documented that ethical theories focus on the ethical requirements that strengthen the relationship between business and society which is based on principles that express the right thing to do or the necessity to achieve a good society. The authors noted that the normative stakeholder theory is a way to integrate social demands. Normative stakeholder theory has a normative core based on two major ideas. Stakeholders are persons or groups with legitimate interests in procedural and/or substantive aspects of corporate activity (stakeholders are identified by their interests in the corporation, whether or not the corporation has any corresponding functional interest in them) and The interests of all stakeholders are of intrinsic value (that is, each group of stakeholders merits consideration for its own sake and not merely because of its ability to further the interests of some other group, such as the shareowners).

Approach maintains that business, as with any other social group or individual in society, has to contribute to the common good, because it is a part of society and it shouldn't be harmful to society. Morimoto and Hope, (2005) are using Grounded Theory approach to undertake the complex issues CSR auditing. According to the authors the grounded theory is 'grounded' in the data; developed from it by the analysis process and tested in the existing data for verification. It is systematic rigor and thoroughness from initial design, through data collection and analysis. institutional theory on CSR comprising a series of propositions specifying the conditions under which corporations are more (or less) likely to behave in socially responsible ways such as financial performance and economic environment, competition, legal environment, private regulation and the presence of independent organizations, business education environment, and employer-employee relations. Another study by Frederiksen, (2010), the author had chosen two kinds of teleological moral theories, i.e. egoism and utilitarianism, and two kinds of deontological moral theories, i.e. libertarianism and common-sense morality and moral theory, i.e. utilitarianism and common-sense morality. From the authors' finding, the companies act in CSR is not according to their CSR policies on goal-oriented teleological moral theories, such as ethical egoism or utilitarianism, but they prefer on duty based common-sense morality. In addition, managers mainly perform with goal-oriented teleological moral the ethical guidelines, utilitarianism and this theory is in disagreement with deontologically oriented theories i.e., common-sense morality. Marimoto et al, (2005) there are six key elements to the achievement of successful CSR are perceived as good stakeholder management, good corporate leadership greater priority for CSR at board level, integration of CSR into corporate policy at all levels and in all divisions of business, regulation at the national and international level understood and demonstrated across all areas of business, active involvement of, and good coordination between, government business, NGOs and civil society. Raps (2005) noted that in order to achieve successful implementation of $\mathrm{CSR}$, there is a need to understand a long-term process that requires creativity and careful planning. The author pointed out ten critical points to overcome and improve the difficulties in the CSR implementation context. Refer to Raps, (2005), the importance of having top-managers working hard to achieve the purpose of the strategy is crucial for the implementation to succeed. Top-managers must influence middle managers in order to get their true message forward; they cannot relay on and believe that the middlemanagers perception of the implementation is the same as theirs. The author pointed out that to make use of the 
knowledge that middle managers possess and make sure they are involved increases their motivation and make them feel like they are a part of the process. This motivation boost is important for everyone's everyday day work since the middle managers engagement increases the awareness of the implementation throughout the organization. Companies can no longer only focus on how to maximize their profit and ignore the consequences that their actions might have on people and environment. Today the debate on wider responsibilities for companies is hotter then ever. This has made the concept Corporate Social Responsibility (CSR) a necessity for companies to adopt in order to increase the responsibilities and to help contributing to a better world. Since CSR is a fairly new topic not many theories or models on the implementation process exist which can assist for companies adopting CSR. CSR implementation is a complex process than theoretical review illustrated. CSR implementation is not a process that follows certain steps in a given order or a process that even has an obvious beginning or end. Instead the CSR implementation process should be seen as something that is going on continuously within an organizations and that is integrated in other parts of the organization and in the daily activities.

What is corporate social responsibility? CSR is a well-known and widely used term in business, government, NGOs, and academia, but there is little agreement about what it means and what it entails (Brei and Böhm 2013). Yet scholars representing multiple academic disciplines (e.g., organizational and management studies, communication and marketing studies, international relations, political theory) are researching and writing about the topic. Buchholtz and Carroll (2008) write that CSR requires that business organizations encompass "the economic, legal, ethical, and discretionary (philanthropic) expectations that society has of organizations at a given point in time". It is often used as an umbrella term that encompasses a range of ethical discourses and practices including business ethics, corporate philanthropy, and corporate citizenship. In these discussions, CSR generally involves discretionary organizational actions which means they are often sporadic, short-term, idiosyncratic, and loosely coupled with other organizational actions and actors. When allowed to select what social problems to focus on corporations will support a very narrow set of social needs and values (Shumate and O'Connor 2010) - those which ultimately will benefit the corporation. Depending on an organization's products and operations, the legal frameworks in the countries where they operate, and the strength of various civil society institutions different issues become the focus of their CSR efforts. To better understand CSR we investigate the definition of responsibility. Responsibility is one of the three key words in CSR. Responsibility is the state, quality, or fact of being responsible. Responsible includes being legally or ethically accountable for the care or welfare of another, personally accountable or having the ability to act without guidance or superior authority, capable of making moral or rational decisions on one's own and therefore answerable for one's behavior, capable of being trusted or depended upon, characterized by good judgment or sound thinking, having the means to fulfill obligations, required to be answerable. We italicize key words in this definition most important to our understanding of CSR. Words like legal or ethically accountable, welfare of another, personal accountability, acting without guidance, rational decision-making, good judgement, and trust place the faith to take action in the hands of individual corporate actors often guided by their own self- interests and operating in changing legal and normative environments. We argue that CSR as practiced by many, but certainly not all, organizations is only loosely related to the word 'responsible'. So CSR often is addressed through voluntary responses to an issue perceived to have ethical components. But it is difficult to identify what ethical obligations exist at a particular time and place. Some argue that corporate actors' fiduciary duty to their stockholders is a moral responsibility. However, increasingly armed with the knowledge of impending climate change challenges key spokespeople for various faith communities are talking about the corporate actors' moral responsibilities to act in humanity's best interests, and taking action themselves.

At its core sustainability is concerned with resource use consistent with the carrying capacity of our planet so as to maintain human life. Elkington (1999) linked corporate sustainability with the idea of the triple bottom line - profits, planets and people. An organization's economic, social, and environmental performance are interconnected. The economic dimension centers on the value creation and enhanced financial performance of an organization's sustainability-related activities. The social dimension encourages organizations to consider their impact on society and addresses issues such as community relations, support for education, and charitable contributions. The environmental dimension involves activities that do not erode natural resources due to prudent corporate environmental management efforts (Allen 2016). Of these three dimensions the social dimension, often constrained by the economic dimension, is most closely related to the issues commonly associated with CSR. Today, sustainability is seen by many to be an attractive, if not necessary, development in how businesses operate. The main argument is there can be a positive relationship between environmental, social, and financial performance. Blackburn (2007) provides seven business case arguments including increased reputation and brand strength; more competitive, effective, and desirable products and services; new markets; productivity; lessened operational burdens and interference; lower supply chain costs; lower cost of capital; and less legal liability. In their review of related theories, research, and tools, Salzmann et al. (2005) conclude that the research does not show a strong causal relationship between the variables. However, a lack of unified findings is not surprising since an organization's performance depends on various organizational dynamics, its industry sector, the magnitude and types of environmental challenges faced, and the tools used to measure environmental, social and financial performance (Allen 2016). The idea of sustainability extends CSR by focusing organizations and researchers on the need to equitably balance environmental and social concerns with economic concerns - a balance rarely really existing in CSR discussions which continue to privilege economic concerns, and to a much lesser extent social concerns. This privileging of economic concerns is evident in how Carroll (1991) described CSR's four segments. A business must pursue maximum profitability as an economic responsibility, be aware of and comply with all laws and regulations, operate in a way that respects the concerns and values of society at large -and adjust to new values and concerns, and support educational, religious, artistic, medical, social welfare, or other charitable endeavors in order to meet its philanthropic responsibilities. Critics argue that CSR often attempts to mask and silence historical struggles within communities and countries. Rather than helping deal with the social, environmental, and economic issues, CSR campaigns can 
actually blur the lines of accountability and responsibility between public and private actors (Brei and Böhm 2013).

Today, CSR can be categorized into two streams (Brei and Böhm 2013), or contrasting perspectives. Some scholars and institutions such as the World Business Council for Sustainable Development (WBCSD) see CSR as a way to fulfill businesses' commitment to economic development while simultaneously improving the quality of life of the workforce, their families, the community, and society at large (Brei and Böhm 2013). From this perspective wider societal aims for development and human well-being are part of the CSR agenda. The second stream of CSR is more focused on the strategic implications of CSR for corporations and less on its effects for society. An organization's financial performance is dependent on successful cooperation with stakeholders and shareholders (i.e., stakeholder management). Corporations are more likely to conduct and discuss CSR projects associated with economic benefits. In the last two decades, corporate involvement in aid and development projects emerged as a powerful corporate discourse because CSR could contribute to profits. Dhanesh (2015) talks about the two contrasting perspectives as involving the moral and the strategic. The moral perspective suggests that businesses engage in socially responsible behaviors because it is "the right thing to do" or they are motivated by intrinsic factors (e.g., ethical values and moral leadership). The strategic perspective suggests that businesses engage in CSR because of extrinsic motivators (e.g., market and institutional pressures) and expected benefits (e.g., profits, increased employee commitment, customer loyalty). A third perspective of CSR combines the two. Given the impending climate challenges being forecast globally it is likely that this third perspective will be the strongest impetus for CSR moving forward. In terms of sustainability, following the Rio de Janeiro Earth Summit of 1992, the WBCSD, which included 162 of the world's largest corporations, primarily represented by the manufacturing, mining and energy sectors, coauthored Changing Course: A Global Business Perspective on Development and the Environment, along with Stephan Schmidheiny (1992). In 2002, at the World Summit on Sustainable Development, the corporate leaders present articulated that business must be a major participant in sustainable development. Interest in sustainability have grown over the past decade. "Multistakeholder engagement among business, government, and civil society, have resulted in a significant number of global voluntary corporate citizenship initiatives". Allen (2016) discusses many of these in terms of their importance to environmental sustainability including the Global Reporting Initiative (environmental reporting), the Carbon Disclosure Project (environmental reporting directed to the investment community), ethical workplace management systems certifications, and sustainability management systems assurance. Some argue such voluntary mechanisms are replacing or preventing regulatory initiatives and therefore setting back real corporate responsibility. However, compliance with voluntary reporting guidelines and certification programs, along with legal changes, are beginning to change the normative environment of how businesses conduct themselves in terms of their environmental and social obligations. Also, such initiatives provide organizations with new metrics that can be utilized to bring about corrective actions. CSR activities and sustainability initiatives are not without critics. There is a growing literature that critically addresses CSR practices and discourses (see Brei and Böhm 2013). Critics argue that short-term CSR actions are ineffective if not dangerous. Cause-related marketing campaigns often associated with CSR efforts allow organizations to make a profit due to global social problems (i.e., limited safe drinking water) especially in developing countries. CSR can function as a depoliticizing marketing practice that cements the role and power of corporate actors without delivering real improvements to people and communities. Critics argue that CSR is increasingly part of the problem, that half-hearted CSR campaigns are not effective, that CSR is just another management fad that supports wider corporate and capitalist ideologies, that CSR can have a devastating impact on workers, local communities and other stakeholders, and that modern CSR scholarship is irrelevant because it fails to articulate a realistic normative position or adequately study its subject. However, it is important to distinguish isolated CSR cause-related marketing campaigns from the more systematic and widespread changes occurring within the business communities as sustainability-related initiatives (e.g., carbon reporting, ethical workplace management systems certifications, sustainability management systems assurances) take hold.

\section{PORTER HYPOTHESIS}

Economists usually associate negative impacts of environmental regulation on firm competitiveness. Porter (1991) and Porter and van der Linde (1995) proposed a different view, however. By relying on a few case studies, they argue that even if stringent regulation imposes costs on affected firms, regulations will trigger innovations which finally overcompensate regulatory costs. This relationship has become known as the Porter hypothesis, or to be more precisely, the "strong" version of the hypothesis, see Jaffe and Palmer (1997). Moreover, Porter and van der Linde (1995) identified both, environmental (social) and corporate (private) benefits to be a result of more stringent environmental regulation. They conclude that environmental regulation improves firms' competitiveness in the long run accompanied with an improved environmental performance. The advocacies of this point of view refer to this as a "double-dividend" or a "win-win" situation. This supposed "win-win" situation has not been untouched by opponents since it does not offer any comparison of costs and benefits of environmental regulation. Such a comparison of the benefits and costs is exactly how one should determine the economic attractiveness of specific programs - not on the false premise of cost-free controls." (Palmer et al. (1995). The approach we decide to adopt is to evaluate the costs and benefits of environmental regulation at the firm level by looking at the profitability effects of regulation-induced innovations. Firm profitability reflects both costs to cope with regulation, as well as either enhancing or decreasing productivity effects of environmental technology. Environmental innovations are new products, processes or procedures (including the adoption of existing technology) that aim at reducing environmental impacts of firm activity or of using firms' products. Such innovation can either be imposed by government regulation or introduced voluntarily. While any environmental innovation is characterised by decreasing environmental externalities, environmental innovation may also increase the innovator's productivity, e.g. by increasing resource efficiency (energy and material consumption per unit of output) or increasing product demand through higher quality characteristics of products. These productivity gains may overcompensate costs of introducing environmental innovations and thus increase firm profitability. In line with 
this argument is the study of Berman and Bui (2001). They pointed to the fact that firms' pollution abatement costs do not correctly predict regulation's impact on their profitability. As they argue, this is the result 1 why the literature founds mixed evidence on the productivity effects of regulation in general. Our approach differs from Berman and Bui (2001) in the way how to unmask the overall firm-level effects of regulation on competitiveness as we look in detail on the profitability consequences of regulation induced innovations. We analyse whether introduced in response to regulation differ in their impact on profitability compared to voluntarily introduced environmental innovations. We distinguish two types of environmental innovations; those reducing environmental externalities and those reducing per unit consumption of environmental costs (energy, materials). We assume the Porter hypothesis not to hold in general, but only for regulation which forces firms to increase efficiency while regulations aiming at lowering externalities will harm firms' profits. In this regard we provide further empirical evidence referring to Porter's hypothesis. This is needed since "the evidence offered in support of this hypothesis is largely anecdotal" (Jaffe and Palmer (1997).

The relationship between technological change and environmental policy has received a lot of attention from scholars and policymakers during the last decades. This is partly because the environmental consequences of social and business activity are affected by the rate and direction of technological change, and also because environmental policy interventions may create new constraints and incentives that may shape the path of future technological development (Jaffe et al., 2003). Environmental technological progress is a very broad phenomenon and every description of it cannot be more than very incomplete. Some examples concern 1) technologies that reduce pollution at the end-of-pipe, such as scrubbers for use on industrial smokestacks or catalytic converters for automobiles 2) technologies that increase user value for consumer products (e.g. medicines) after introducing new production methods, which, at the same time, decrease the environmental burden of their production by using materials that are less harmful for the environment and 3) implementation of technologies that are targeted to changes in production processes to improve energy efficiency. Policy responses to environmental problems often start from the assertion that the link between overall technological change and (e.g.) climate based environmental policies is merely macro oriented. However, for understanding the interaction between environmental policy and technology it also makes sense to go down to the micro level. After all, environmental regulation and public funding of $R \& D$ are the first impetus to have more green technologies developed by individual firms. Similar to other types of innovations, the benefits of environmental technological innovations may accrue to society at large rather than to the adopter of these new technologies alone. This market failure related to innovation in general is pivotal to the numerous discussions surrounding the so-called Porter-Hypothesis $(\mathrm{PH})$. It is often argued that one cannot find a 10-Dollar bill on the ground, because if it was there, somebody else would already have picked it up. This metaphor neglects three things 1) that market forces alone do not provide enough incentives for firms to be engaged in green innovation and 2) that green innovation is not very different compared to innovation in general and 3) that policy responses such as environmental regulation have a role to play to bring economic opportunity in line with the environment (see e.g. Jaffe et al., 2002). The central issue is the question whether regulation drives innovation. The $\mathrm{PH}$ asserts that polluting firms can benefit from environmental policies, arguing that well designed and stringent environmental regulation (ER) can stimulate innovations, which in turn increase the productivity of firms or the product value for end users (Porter, 1991; Porter and van der Linde, 1995). The message of this hypothesis is that there seems to be no trade-off between economic growth and environmental protection but a win-win situation instead. Environmental regulation would benefit both society and regulated firms by triggering dynamic efficiency of firms and these benefits may partially or fully offset the costs of complying with environmental restrictions. It is an important question can environmental regulation in the country support competitiveness. Porter and van der Linde go on to explain that there are at least five reasons that properly crafted regulations may lead to these outcomes: First, regulation signals companies about likely resource inefficiencies and potential technological improvements. Second, regulation focused on information gathering can achieve major benefits by raising corporate awareness. Third, regulation reduces the uncertainty that investments to address the environment will be valuable. Fourth, regulation creates pressure that motivates innovation and progress. Fifth, regulation levels the transitional playing field. Finally, they note, "We readily admit that innovation cannot always completely offset the cost of compliance, especially in the short term before learning can reduce the cost of innovation-based solutions" (Porter and van der Linde 1995). The Porter Hypothesis has met with great success in political debate, especially in the United States, because it contradicts the idea that environmental protection is always detrimental to economic growth. The Porter Hypothesis has been invoked to persuade the business community to accept environmental regulations, as it may benefit from them in addition to other stakeholders. In a nutshell, well-designed environmental regulations might lead to a Pareto improvement or "win-win" situation in some cases, by not only protecting the environment, but also enhancing profits and competitiveness through the improvement of the products or their production process or through enhancement of product quality. Innovation Strict but Flexible Environmental Regulations. Indeed, the hypothesis rests on the idea that firms often ignore profitable opportunities. In other words, why would regulation actually be needed for firms to adopt profit-increasing innovations? In fact, Porter directly questions the view that firms are profitmaximizing entities: "The possibility that regulation might act as a spur to innovation arises because the world does not fit the Panglossian belief that firms always make optimal choices." As discussed below, firms might not appear to be making optimal choices for many reasons, such as imperfect information or organizational or market failures. Moreover, even if systematically profitable business opportunities are missed ("low hanging fruits"), the next question is, how could environmental regulations change that reality? Are regulators in a better position than managers to find these profitable business opportunities? Porter argues that environmental regulation may help firms identify inefficient uses of costly resources. They may also produce and disseminate new information (e.g., best-practice technologies) and help overcome organizational inertia. There is much confusion in the literature about what the Porter Hypothesis actually says. As we note above, it does not say that all regulation leads to innovation-only that well-designed regulations do. This is consistent with the growing trend toward performance-based and/or marketbased environmental regulations. Second, it does not state 
that this innovation necessarily offsets the cost of regulation - that is, it does not claim that regulation is always a free lunch. Instead, it does make the claim that in many instances, these innovations will more than offset the cost of regulation-in other words, there may be a free lunch in many cases. Younger machines are more productive and less polluting than older machines, but are more costly to buy and to install in the capital stock. Stricter environmental regulation, in the form of an increase in the emission tax, will reduce the number of machines of all ages and therefore the size of the firm. However, the same tax increase generally also reduces the average age of the capital stock and thus increases its productivity. It follows that two effects can be distinguished: a "downsizing" effect and a "modernization", effect. Downsizing refers to the reduction of the total capital stock.3 Modernization refers to the reduction of the average age of this capital stock. Environmental regulation accelerates the removal of older machines from the capital stock which increases its productivity. 4 It is important to note here that in the actual practice of environmental policy, existing capital is often exempted from the new and stricter regulation. The effects analysed in this paper then only occur for the ages of the capital stock on which the higher tax is levied. As a consequence, modernization is less than in case all ages of the capital stock are subject to environmental regulation. The extra tax burden and the shift in investments and output are not profitable for the firm. This cost of environmental regulation is, however, mitigated by three effects: downsizing leads to an upward pressure on prices, modernization leads to a higher productivity of the capital stock, and downsizing and modernization together lead to lower emissions, so that an environmental target can be reached with a lower tax than in the absence of this effect. In this paper a situation with homogeneous capital, where only downsizing occurs, is compared to a situation with heterogeneous capital, where also modernization occurs. It is shown that the marginal decrease in profits is lower and the marginal decrease in emissions is higher in the second situation. The implication for the debate on the Porter hypothesis is not that a win]win situation can be expected, but the trade-off between improving the environment and the competitiveness of the home industry is not as grim as it is sometimes suggested because of favourable changes in the composition of the capital

\section{BUSINESS SUSTAINABILITY AND COMPETITIVENESS OF ENTERPIRISES}

Michael Porter and Mark Kramer propose a fundamentally new way to look at the relationship between business and society that does not treat corporate growth and social welfare as a zero-sum game. They introduce a framework that individual companies can use to identify the social consequences of their actions; to discover opportunities to benefit society and themselves by strengthening the competitive context in which they operate; to determine which CSR initiatives they should address; and to find the most effective ways of doing so. Perceiving social responsibility as an opportunity rather than as damage control or a PR campaign requires dramatically different thinking - a mind-set, the authors warn, that will become increasingly important to competitive success (Porter, Kramer 2006). IMD asked 1,500 managers in nine industry sectors whether they felt there was a business case for sustainability. The answers they received surprised some people. "Many of our respondents complained about a weak and rather elusive business case due to external stakeholders' significant disinterest or even opposition to corporate sustainability," explains IMD's professor Ulrich Steger. To validate their findings IMD surveyed the stakeholders themselves. After analysing 265 interviews and 370 questionnaires, Steger and his team claim to be able to shed more light on how nine different stakeholders, including financial institutions, governments, communities, unions, NGOs and the media, perceive and influence corporate sustainability. And it seems that things have changed little over the last four years. "Overall, stakeholders exhibit significant disinterest in corporate sustainability," Steger says. "They are primarily concerned about companies financial performance and competitiveness in today's global markets." This is due to a significant imbalance of power between different groups of stakeholders, explains Steger. "Customers and shareholders are still calling the shots and are generally not exerting much pressure on corporate social and environmental agendas beyond compliance. Given these circumstances, NGOs - as the most demanding stakeholder group - find it difficult to get the necessary buy-in from other stakeholders for their campaigns. The result is largely incremental social and environmental progress in companies." In the light of companies' significant bargaining power, it is not surprising that stakeholders such as governments, communities and unions tend to adopt a collaborative approach to influence them, according to Steger. Many NGOs have also attempted to move beyond their traditional advocacy stance, taking part in stakeholder dialogues and in some cases forming partnerships with the corporate sector. But this approach is highly controversial in the NGO sector and can allow companies to operate in a relative comfort zone surrounding by plenty of carrots but a distinct absence of sticks, Steger says. Many of the stakeholders interviewed for the survey expressed concern over a perceived non-level playing field between firms operating in different parts of the world. Europe, for example, has high social and environmental standards, but this cannot be said of developing countries and emerging economies. One interviewee commented: "It will be interesting to see what is done about China; there is pressure on jobs in Europe. Ultimately, social and environmental criteria may even be used as a trade barrier with quotas and claims of low labour standards and low environmental standards. There is already some noise being made. This is likely to be more significant in the future."But while companies need not worry about increasing pressure right now, things could change. "It would be dangerous to be complacent," says Steger. "After all, one of the few 'iron laws' is that to maintain power, one has to use it responsibly. (Steger 2004)

Governments are beginning to view corporate social responsibility as cost-effective means to enhance sustainable development strategies, and as a component of their national competitiveness strategies to attract foreign direct investment and position their exports in global markets. Company 
strategy and public policy are alike concerned to match supposed international challenges. This also increasingly affects individuals, who are also required to become competitive in the way they conduct their lives, these demands going under the headings of being flexible, innovative, imaginative entrepreneurial, etc. Companies create external effects through their operations or actions. These effects can be positive - for example spill over effects from research and income multiplier effects in local communities - or negative, a classical example being pollution. It is expected that governments or other entitites that are external to the market relevant costs if the impact of the externalities is not acceptable to important stakeholders, for example the investment and operational costs of pollution control equipment (Steger, 2004). People often use the word sustainability when discussing economic development, environmental stress, and the role of the corporation in society. Definitions of the world vary widely in scope: some are focused tightly on economic and environmental considerations, while others encompass equity, various definitions of justice, and other social criteria. Definitions that are focused enough to be readily translated into measurable performance indicators may be thought too narrow to capture all the relevant considerations. Broader definitions, attractive by virtue of their comprehensiveness, may be extremely difficult to translate into measurable indicators and hence into workable policies for governments or businesses. Development process play crucial roles in any process affecting the exploration, utilisation and conservation of natural resources. Hence the need to harness this capacity to meet the projected higher needs for these resources, associated with future development and population growth, as well as their conservation for future generations. Not only that they provide the cutting edge for exploiting known resources, but also provide basis for new knowledge of potentials. As new techniques will result in reduced costs per unit of output, they would also help ensure the sustainability of development and thereby contribute to averting the otherwise ominous prospects of depletion of/or serious degradation of natural resources which, if it occurs, would seriously impair future growth and development. While there are a number of ways that development process could contribute to the effective exploitation of natural resources, priority should be given to areas where efficiency, increased availability and sustainability could be ensured. Environmental, social, institutional and economic developments are strongly linked. They are crucially important for the well being of the current as well as future generations. The term sustainability evokes the image of an economic system able to evolve without deterioration from its current state into the longterm future, being in balance with nature. This balance may be as much psychological as material and energetic (O'Connor 1998). On business level we can see the balance among investors, suppliers, consumers, local community and competitors. Being socially responsible means not only fulfilling legal expectations, but also going beyond compliance and investing more into human capital, the environment and the relations with stakeholders. The experience with investment in environmentally responsible technologies and business practice suggests that going beyond legal compliance can contribute to company's competitiveness. Going beyond basic legal obligations in the social area, for example, training, working conditions, management-employee relations, can also have a direct impact on productivity. It opens a way of managing change and of reconciling social development with improved competitiveness. Effects of corporate sustainability management are of great interest to both companies and society. In particular, its micro level economic effects are often the subject of debates and studies discussing the importance and robustness of a business case for corporate sustainability. Obviously these effects are of major importance to promoters and critics of CSM (corporate sustainability management), so is their qualification (Slazmann et al, 2005). We are implementing the new european strategy for CSR. A new strategy on Corporate Social Responsibility ('CSR'), which aims to take forward the contribution of business to sustainable development, was adopted by the European Commission. The strategy calls for a new social and environmental rôle for business in a global economy and sets up a 'European Multi-Stakeholder Forum' for all players social partners, business networks, civil society, consumers and investors to exchange best practice, to establish principles for codes of conduct and to seek consensus on objective evaluation methods and validation tools such as 'social labels'. The strategy seeks to complement existing initiatives by companies themselves and by public organisations such as the OECD and the UN. CSR is defined as voluntary social and environmental practices of business, linked to their core activities, which go beyond companies' existing legal obligations. The strategy will also support CSR in small and medium-size undertakings ('SMEs'), in particular by identifying the business case for CSR and by awareness raising of SMEs. The Commission has an important role to play in CSR, bringing together businesses across Europe to share best practice and to establish common principles for evaluation. Finally, the Commission will work towards building CSR principles into all other EU policies, for example by promoting better understanding of CSR. We can see the CSR as achieving commercial success in ways that honor ethical values and respect people, communities, and the natural environment. CSR means addressing the legal, ethnical, commercial and other expectations society has for business, and making decissions that fairly balance that claims of all key stakeholders. CSR is viewed as a comprehensive set of policies, practices and programmes that are integrated into business operations, supply, chans, and decision-making processes throughout company, wherever the company does business and includes responsibility for current and past actions as well as future impact. The main function of the enterprise is to create value through producing goods and services that society demands, thereby generating profit for its owners and shareholders as well as welfare and society, particulary through an ongoing process of job creation.

\section{CORRELATIONS BETWEEN DETERMINANTS OF SUSTAINABLE DEVELOPMENT}

Environmental performance requires improvements in a country's institutional foundations. Without institutional quality, we cannot accept the stronger environmental standards and laws. In practice, a nation's economic and legal context and its environmental regulatory regime are connected. This association demands further exploration, but the preliminary evidence developed here suggests that countries would benefit environmentally from an emphasis on developing the rule of law, eliminating corruption, and strengthening their governance structures. The strong association between income and environmental performance also carries important implications. Among other things, it provides powerful corroboration for a policy emphasis on 
poverty alleviation and the promotion of economic growth as a key mechanism for improving environmental results. The correlations are calculated among economic, social and environmental indicators. The Sperman correlation coefficient is used. In principle, $\rho$ is simply a special case of the product-moment coefficient in which the data are converted to ranking before calculating the coefficient. In practice, however, a simpler procedure is normally used to calculate $\rho$. The raw scores are converted to ranks, and the differences $d$ between the ranks of each observation on the two variables are calculated.
If
$\neg \exists_{i, j} i \neq j \wedge\left(x_{i}=x_{j} \vee y_{i}=y_{j}\right)$ given by:

$$
\rho=1-\frac{6 \sum d_{i}^{2}}{n\left(n^{2}-1\right)}
$$

where:

$d_{i}=$ the difference between each rank of corresponding values of $x$ and $y$, and

$n=$ the number of pairs of values.

Table 1. Correlations between economic and environmental indicators in Slovenian SD system

\begin{tabular}{c|c|c|c|c|c|c|c|c|c|c|c|c}
\hline & 1 & 2 & 3 & 4 & 5 & 6 & 7 & 8 & 9 & 10 & 11 & 12 \\
\hline $\begin{array}{c}\text { 1. GDP per capita } \\
\text { (USDpp) }\end{array}$ & 0.752 & -0.030 & -0.119 & 0.412 & 0.476 & 0.433 & 0.165 & -0.549 & 0.709 & 0.168 & 0.203 \\
\hline 2. Expenditures for R\&D & & 0.809 & 0.799 & 0.390 & 0.588 & -0.105 & 0.048 & -0.576 & 0.659 & -0.445 & -0.303 \\
\hline $\begin{array}{c}\text { 3. Number of hosts per } \\
100 \text { habitants }\end{array}$ & & & 0.753 & 0.515 & 0.612 & 0.309 & -0.009 & 0.511 & 0.651 & -0.002 & 0.225 \\
\hline $\begin{array}{c}\text { 4. Users of internet per } \\
\text { 100 habitants }\end{array}$ & & & & 0.492 & 0.614 & -0.035 & 0.149 & -0.419 & 0.642 & -0.142 & -0.358 \\
\hline $\begin{array}{c}\text { 5. Number of permissions } \\
\text { to start a business }\end{array}$ & & & & & 0.800 & 0.075 & -0.311 & -0.564 & 0.181 & 0.340 & 0.266 \\
\hline $\begin{array}{c}\text { 6. Number of days to start } \\
\text { a business }\end{array}$ & & & & & & 0.007 & 0.315 & -0.383 & 0.360 & 0.094 & 0.110 \\
\hline 7. Density of the roads & & & & & & & -0.425 & -0.293 & -0.305 & 0.440 & 0.379 \\
\hline $\begin{array}{c}\text { 8. Renewable energy } \\
\text { production }\end{array}$ & & & & & & & & 0.140 & 0.298 & -0.226 & -0.318 \\
\hline 9. Emissions CO2/capita & & & & & & & & & -0.147 & -0.439 & 0.523 \\
\hline 10. Emissions SO2/capita & & & & & & & & & & -0.235 & 0.153 \\
\hline 11. Emissions SO2 & & & & & & & & & & & 0.009 \\
\hline 12. Emissions NOx/capita & & & & & & & & & & & \\
\hline
\end{tabular}

Source: own evaluation

In the table above the strongest correlation can be seen in the economic-environmental group of indicators between GDP per capita (ppp) and emissions of SO2 per capita (0.709). There is also a strong correlation between expenditures for R\&D and emissions SO2/capita (0.659). A strong correlation can be seen between expenditures for R\&D and certificates ISO 14001 (0.645). Entrepreneurship sustainability is connected with technological progress. The users of Internet per 100 habitants have a positive correlation with emissions SO2/capita (0.642). Therefore, it can be concluded that the information technology development has a positive influence on air pollution.

\section{CSR IN CENTRAL EUROPE}

Corporate social responsibility (CSR) and sustainable development are all new concepts that were mostly unknown through Central Europe less than 20 years ago. Today we can see a growing number of companies in our region that consistently follow in the footsteps of the most advanced global enterprises, implementing strategic initiatives and thus increasing their contribution to sustainable social and economic growth. This year we decided to check the level of CSR maturity of companies in Central Europe. The Deloitte report (2016) is a first ever attempt to look at CSR practices in ten Central European countries: Bulgaria, Czech Republic, Kosovo, Lithuania, Latvia, Romania, Serbia, Slovakia, Slovenia and Hungary. In addition to Deloitte's survey in Central Europe, the Forum and market research company PBS conducted the same survey among CSR managers in Poland. Both surveys show the role of CSR practitioners in promoting social responsibility in companies as well as their insights on the positive effects of CSR on the social and economic condition of each country. One of the main conclusions found in this survey is that the majority of CSR managers in Central Europe (84\%) believe business has played a role in solving social and economic problems in individual countries, in particular protecting the natural environment, supporting education and counteracting unemployment. CSR managers see the best chances for social and economic development of their countries in the impact of business on the growth in the competitiveness of the economy, the positive impact of enterprises on employment rates and aligning work availability with actual needs as well as their impact on the knowledge-based economy and intellectual capital growth. To a great extent, this change will be a result of pressure coming from customers who are increasingly expecting to see socially responsible products and services on the market (75\%). This change, however, may be met with a few obstacles. Respondents of the survey expressed that some of the main obstacles for sustainable economic and business growth are the wrong perception of CSR as a form of sponsoring, a lack of incentives from the state administration and businesses' reluctance to invest in CSR initiatives. As a provider of CSR services to the private and public sector of Poland and 16 other European countries, we can see great potential for further development and professionalization of CSR services in our region. This potential was backed by our survey, which found that $76 \%$ of our respondents saw the potential for future development. Business has a very important role to play in this area, but it 
needs to receive support from the public sector $(52 \%$ of the respondents from Central Europe complain about a lack of incentives from the state administration). The role of businesses should be to shape their national policies and implement the principles of low-emission, circular economy, energy efficiency as well as sustainable urban and rural development. We can see a lot of room for cooperation with and education of all stakeholders. We have illustrated the results of our survey with quotations taken from CEOs from the region that we gathered during our work on the Deloitte Central Europe 2015. This year, for the first time in the history of the CE Top 500 survey, Deloitte asked the respondents about their sustainable development practices. As it turns out, one fourth of the companies included in the ranking declare that they do measure their own impact on the economy, society and the environment (mostly companies from the Czech Republic, Slovakia and Poland). Over one fifth of the biggest firms in Central Europe (109) state that they do have a form of non-financial disclosure reporting in place or they plan on reporting non-financial information for 2015. Data disclosed in impact reports and non-financial disclosures enable companies to make informed decisions concerning the management of their own impact, engage in a dialogue with their immediate environment and support social initiatives. This form of involvement lets companies get to know their stakeholders' expectations and needs so that they can be taken into account when making business decisions. This is how companies can maximise the benefits and minimise the negative effects of their business activity.

Deloitte made a survey in business sector in Central Europe about CSR. The award of the best corporate sustainability report in the Central European region goes to the Czech Republic. For the very first time, a Czech company took first place, namely. The runners-up were the Polish Bank Zachodni and the Croatian oil company INA - Industrija nafte. In the 15th annual Deloitte Green Frog Award, the international jury evaluated a total of 76 corporate reports from seven Central European countries. "It is evident from the report that the company has set a clear strategy in the area of sustainable development. It is easy to understand and above all, it presents a high level of CSR activities and sustainability. Other award-winning companies from the Central European region included the Polish Bank Zachodni, the Croatian oil company INA - Industrija nafte, Slovenian Petrol or Ursus Breweries from Romania. CSR reports have become a tradition with increasing importance in Central and Eastern Europe; more than 50 out of 109 large companies have published a non-financial report in some form. The majority of the companies were based in the Czech Republic, Hungary, Croatia, Slovenia and Poland where almost 300 such reports already exist and around 40 new reports are added every year. This trend is corroborated by the increasing number of companies applying for the Green Frog Award, despite the fact that non-financial reporting has not yet been obligatory in Europe. This, however, will change as soon as next year when the respective EU directive will come into force, obliging companies to also publish non-financial information related to their activities. The Green Frog Award can thus help companies prepare for this new legislation. About Green Frog Award. Deloitte has awarded the Green Frog Award for the best non-financial report on sustainable development to companies operating in Central Europe since 2000. Czech companies or firms active in the Czech Republic can apply, irrespective of their industry and size. The basic condition is publishing a report on sustainability, environmental policy or CSR in English (either separately or as part of the company's annual report). Publishing nonfinancial reports has so far been voluntary, but from 2017, it will be obligatory pursuant to an EU directive. According to a 2015 survey by Deloitte, $63 \%$ of CSR managers expect that this directive will have a positive impact on the quality of non-financial reports in their country. The members of the jury included experts from organisations such as the Global Reporting Initiative (GRI), Business Council for Sustainable Development in Hungary (BCSD), the Polish Ministry of Economic Development and the Croatian Ministry of Environmental and Nature Protection. According to CSR Managers from 10 Central European countries:

- business has had a positive effect on finding solutions to social problems within their countries in recent years, especially in solving environmental problems, supporting education and counteracting unemployment

- social and economic development in their countries could be achieved through the impact of business on growth of competitiveness in the economy, the positive impact of enterprises on employment rates, aligning work availability with actual needs, and business impact on the knowledgebased economy and intellectual capital growth

- business models are likely to change in the coming years, and to a great extent, the change will be the result of pressure from customers who are increasingly expecting to see socially responsible products and service on the market

- CSR will flourish in their countries in the future with a continued growth in the number of socially responsible businesses and more and companies including social and environmental in their business models

- the wrong perception of CSR as a form of sponsoring, a lack of incentives from the state administration and businesses' reluctance to invest in CSR initiatives are the biggest obstacles to CSR development in the future

- CSR has benefitted their companies internally by increasing employees' involvement and raising their ethical awareness and externally by improving the company's reputation and recognition of the brand as socially responsible

- the most effective CSR methods and tools consist of corporate volunteering, ethical programmes for employees, and dialogue with stakeholders

\section{CONCLUSION}

Corporate Social Responsibility can be understand as a way for managing business activities which integrates economic, social and environmental aspects in harmony with principles of sustainable development that have a positive impact not only on our economic performance but also on our surroundings (employees, partners, customers, the city and region) with a consistent reduction of impacts on the environment via enduring development of human resources, the community and society. It is our continuous obligation to do business ethically, transparently and in accord with CSR principles and to contribute to the economic environment along with improvement in the quality of life of our employees, their families, the local community and, equally also, in society in the broader meaning of this word. All hypothesis in the article stands.

In the article I have analysed strong correlations among economic and environmental indicators. The strongest correlation can be seen in the economic-environmental group of indicators between GDP per capita (ppp) and emissions of SO2 per capita $(0.709)$. There is also a strong correlation 
between expenditures for R\&D and emissions SO2/capita (0.659). A strong correlation can be seen between expenditures for R\&D and certificates ISO 14001 (0.645). Entrepreneurship sustainability is connected with technological progress. The users of Internet per 100 habitants have a positive correlation with emissions SO2/capita (0.642). Therefore, it can be concluded that the information technology development has a positive influence on air pollution. Enterprises on the other side don't see a special profit by implementation of CSR (Corporate social responsibility). Management have a low opinion about wide consens by achiving environmental and social goals. Among incentives of sustainable development in enterprises have better social conditions in the whole chain value a special weight. Better business ethnics is an important incentive of sustainable development on entrepreneurship level. On the other side harder involvement of community doesn't bring an important incentive for sustainable development. Educational programmes have to implement the sustainable development. CEE enterprises give a special attention to pollution, health and security. On the other side can be seen a low interest to poverty and prices. The biggerst barriers toward sustainable management are organisation culture, and low interest by consumers. On the other side is a low barrier a directions of management. The state regulation is also a low barrier toward sustainable management. Business sustainability is well developed in CEE companies. European single market support the more ecological and social orientation of enterprises.

\section{LITERATURE}

1. Allen, M. W. (2016). Strategic communication for sustainable organizations: theory and practice. New York: Springer Publishing Company.

2. Becker-Olsen, K. L., Cudmore, B. A., \& Hill, R. P. (2006). The impact of perceived corporate social responsibility on consumer behavior. Journal of Business Research, 59 (1), pp 46-53

3. Beckman, Terry Alison Colwell and Peggy $\mathrm{H}$. Cunningham, 2009. The Emergence of Corporate Social Responsibility in Chile: The Importance of Authenticity and Social Networks, Journal of Business Ethics 86: pp 191-206

4. Berman, E., and L.T.M. Bui (2001), Environmental Regulation and Productivity: Evidence from Oil Refineries, Review of Economics and Statistics 83(3), pp 498-510

5. Besley, T., Ghatak, M., 2007. Retailing public goods: The economics of corporate social responsibility. Journal of Public Economics 91(9), 1645-1663.

6. Boyd, E., Spekman, R., Kamauff, J. and Wehane P. (2007) "Corporate social responsibility in global supply chains: a procedural justice perspective", Long Range Planning, Vol. 40, No. 3, pp 341-356

7. Brei, V., \& Böhm, S. (2013). 'I L $=10 \mathrm{~L}$ for Africa': Corporate social responsibility and the transformation of bottled water into a 'consumer activist' commodity. Discourse and Society, pp 1-29.

8. Buchholtz, A. K., \& Carroll, A. B. (2008). Business and society: ethics and stakeholder management (7th ed.). Mason: Southwestern Cengage Learning.
9. Dahl, A.L. (2005) The Competitive Edge in Environmental Responsibility, in The Global Competitiveness Report 2004-2005, WEF Geneve

10. Carroll, A. B. (1991). The Pyramid of Corporate Social Responsibility: Toward the Moral Management of Organizational Stakeholders. Business Horizons, 34, p. 39-48.

11. Dhanesh, G. S. (2015). Why corporate social responsibility? An analysis of drivers of CSR in India. Management Communication Quarterly, 29, pp 114-29

12. Dyllick, T. (1999) Environment and Competitiveness of Companies, International management benchmarks

13. Elkington, J. (1999). Cannibals with forks: the triple bottom line of 21 st century business. Gabriola Island: New Society Publishers.

14. Esty, D. (2001) Digital Earth: Saving the Environment, OECD Observer (May 2001) OECD Paris

15. Esty, D. (2002) Why Measurement matters, Environmental Performance Measurement 20012002, IMD Lausanne

16. Esty, D., Porter, M. (1998) Industrial Ecology and Competitiveness, Journal of Industrial Ecology Vol 2, No. 1 (winter 1998)

17. Esty, D., Porter, M. (2002) National Environmental Performance Measurement and Determinants, Environmental Performance Measurement 20012002, IMD Lausanne

18. European Commission, (2016) Sustainable development in the European Union, Sustainable development indicators, Brussels

19. European Commission (2016) European strategy on Corporate Social responsibility, Brussels

20. Faucheux S, Nicholai I (1998). Environmental Technological Change and governance in Sustainable Development Policy, Ecol. Econ. 3(27):243-256 Fischer K, Scot J (1993). Journal of Environmental Economics and Management, 2(37):165-182

21. Frederiksen, C.S. (2010). The Relation Between Policies Concerning Corporate Social Responsibility (CSR) and Philosophical Moral Theories - An Empirical Investigation. J. Bus. Ethics, 93: 357-371.

22. Garriga, E. and Mele, D. (2004) Corporate social responsibility theories: Mapping and territory. Journal of Business Ethics, 53, pp 51-74.

23. Gminden, C.U. Bieker, T. (2002) Managing CSR by using the Sustaianble Balanced Scorecard, International Conference of the Greening of the Industry Network

24. Jaffe, A.B. and K. Palmer (1997) 'Environmental Regulation and Innovation: A Panel Data ... Review of Economics and Statistics 79.4 (November 1997): 610-19.

25. Jaffe, A., R. G. Newell, R. N. Stavins. (2002) Environmental policy and technological change. Environmental and Resource Economics 22(1) 4169. 
26. Jaffe, A., Newell, R., Stavins, R., (2003). "Technological change and the environment". In: Maler, K.G., Vincent, J.R. (Eds.), Handbook of Environmental Economics, vol. 1. Elsevier, Amsterdam.

27. Ledwidge, J. (2007): Corporate social responsibility: the risks and opportunities for HR. In.: Human resource management international digest, 15 (6), pp. 27-30.

28. Levy, M. (2002) Measuring nation's Environmental Sustainability, Environmental Performance Measurement 2001-2002, IMD Lausanne

29. Levy, M., Maier, P. (2004) Early Warning and Assessment of Environment, Conflict and Cooperation, UNEP and Woodrow Wilson Center

30. Margolis, J., Elfenbein, H., and Walsh, J. (2007), 'Does It Pay To Be Good? A Meta-analysis and Redirectionof Research on the Relationship Between Corporate Social and Financial Performance', Working Paper,Harvard Business School.

31. Morimoto, R., Ash, J., \& Hope, C. (2005). Corporate social responsibility audit: From theory to practice. Journal of Business Ethics, 62, 315-325

32. Mullerat, R (2013) Corporate Social Responsibility: A European Perspective Ramon Mullerat, The Jean Monnet/Robert Schuman Paper Series Vol. 13 No.6 June 2013

33. O'Connor, M. (1997) "Environmental Valuation from the Point of view of Sustainability" in Dragun, A.K., Jacobbson, K.: Sustainability and Global Environmental Policy, Edward Elgar: Cheltenham, pp 149-80

34. OECD, (2002) Overview of Sustainable Development indicators used by national and international agencies, OECD Statistical working paper 2002/1, OECD Paris

35. Owens, S., Cowell, R. (1994) Land and Limits, Interpreting sustainability in the planning process, Routledge, London

36. Palmer, K., W.E. Oates, and P.R. Portney (1995), Tightening Environmental Standards: The Benefit-
Cost or the No-Cost Paradigm? Journal of Economic Perspectives 9(4), 119-132.

37. Porter, M., van der Linde, C. (1995); Toward a new Conception of Environmental Competitiveness Relationship, Journal of Economic Perspectives Vol. 9. No. 4 (fall 1995)

38. Porter, M.K., Kramer, M.R. (2006) Strategy and Society: The Link Between Competitive Advantage and Corporate Social Responsibility, Harvard Business Review, ( DECEMBER 2006 ISSUE), pp 78-92

39. Pyle in Forrant, (2002) Globalization, Universities and issues of Sustainable Human Development, Edward Elgar Cheltenham

40. Raps A. (2005) Strategy Implementation - an Insurmountable Obstacle? Handbook of Business Strategy. 6 (1), pp. 141-146.

41. Reinhardt, F. (2003) Tests for Sustainability, in The Global Competitiveness Report 2002-2003, WEF Geneve, pp 355-366

42. Walley, N., Whitehead, B. (1994) It is Not Easy Being Green, Harvard Business Review Vol 72, No 11-12 (May-June 1994) pp 46-52

43. Salzmann, O., Ionescu-Somers, A., Steger, U. (2005) The Business Case for Corporate Sustainability: Literature Review and Research Options, European Management Journal Vol. 23, No. 1, pp. 27-36

44. Schmidheiny, S. with the Business Council for Sustainable Development. (1992). Changing course: a global business perspective on development and the environment. MIT Press.

45. Shumate, M., \& O'Connor, A. (2010). The symbiotic sustainability model: conceptualizing NGO-corporate alliance communication. Journal of Communication, 60, 577-609.

46. Steger, U. (2004) The Business of Sustainability, Palgrave MacMillan, New York. World Academy of Science, Engineering and Technology pp 30-44

47. Van Marrewijk, M.: Journal of Business Ethics, Vol. 44, No. 2/3, Corporate Sustainability Conference 2002: The Impact of CSR on Management Disciplines (May, 2003), pp. 107-119 